\title{
PENERAPAN ASSOCIATION RULE MINING UNTUK ANALISIS PENEMPATAN TATA LETAK BUKU DI PERPUSTAKAAN MENGGUNAKAN ALGORITMA APRIORI
}

\author{
${ }^{1}$ M. Afdal, ${ }^{2}$ Muhammad Rosadi \\ ${ }^{1,2}$ Program Studi Sistem Informasi, Fakultas Sains dan Teknologi UIN Suska Riau \\ Jl. HR Soebrantas KM.18 Panam Pekanbaru - Riau \\ Email: ${ }^{1}$ m.afdal@uin-suska.ac.id, ${ }^{2}$ muhammad.rosadi@students.uin-suska.ac.id
}

\begin{abstract}
ABSTRAK
Perpustakaan adalah sebagai gedung yang memiliki koleksi bahan pustaka (buku, majalah danmedia lainnya) yang ditata atau diatur dengan cara tertentu agar mudah dimanfaatkan oleh pengguna secara cepat dan tepat. Perpustakaan Soeman Hs memiliki 60.583 judul dan 335.745 buku. Berdasarkan hasil wawancara dalam melakukan penempatan buku diperpustakaan, buku diletakan berdasarkan kategori buku yang telah diberikan penomoran yang disebut dewey decimal classification (DDC). Namun, dalam penempatan buku belum diatur dengan melihat tingkat keseringan pengunjung dalam meminjam buku tersebut. Selain itu, pengujung kesulitan dalam mencari kembali keberadaan buku yang sering dipinjam. Untuk mengatasi masalah tersebut, maka pada tugas akhir ini penulis akan mencari buku yang sering dipinjam secara bersamaan oleh pengunjung, dengan menganalisa data transaksi peminjamaan buku menggunakan metode association rule mining. Tugas akhir ini menggunakan Algoritma Apriori. Dari data 11.550 transaksi peminjaman buku selama 3 tahun yang telah diproses menghasilkan 4 rules dengan kombinasi item terbesar adalah kategori buku agama dan ilmu sosial sering dipinjam secara bersamaan dengan nilai support $11,71 \%$ dan confidence $41,43 \%$. Selain itu, kategori buku teknologi dan ilmu sosial sering dipinjam secara bersamaan dengan nilai support $13,8 \%$ dan confidence $40,75 \%$. Berdasarkan hasil tersebut disaran kepada pustakawan untuk menempatkan buku-buku tersebut pada rak yang berdekatan berdasarkan kategori buku.
\end{abstract}

Kata Kunci: Algoritma Apriori, Buku, Data Mining, Perpustakaan, Transaksi Peminjaman Buku

\section{A. PENDAHULUAN}

Data mining adalah suatu teknik yang digunakan untuk mengelola himpunan data menggunakan metode data mining untuk menghasilakan informasi atau pengetahuan.

Perpustakaan adalah institusi pengelola koleksi karya tulis, karya cetak, dan atau karya rekam secara professional dengan sistem yang baku guna memenuhi kebutuhan pendidikan, penilitian, pelestarian, informasi, dan rekreasi para pemustaka [1]. Perpustakaan Soeman HS merupakan perpustakaan terbesar di Provinsi Riau dan dikelola oleh Dinas Perpustakaan dan Kearsipan Provinsi Riau. Perpustakaan Soeman Hs menyediakan bahan bacaan seperti buku, majalah umum, dan kamus. Jumlah koleksi buku yang ada diperpustakaan Soeman HS 60.583 judul dan 335.745 eksemplar buku dan dikelompokan menjadi 10 kategori buku. Pengunjung yang terdaftar menjadi anggota perpustakaan sebanyak 5.390 orang.

Dari tahun 2016-2018 didapatkan data transaksi peminjaman buku sebanyak 67.356 data.Data transaksi peminjaman buku hanya digunakan sebagai laporan untuk mengevaluasi koleksi yang buku ada diperpustakaan, namun belum dimanfaatkan untuk mengetahui informasi tentang kategori buku yang sering dipinjam secara bersamaan oleh pengunjung. Pada saat ini proses penempatan letak buku yang dilakukan di perpustakaan disusun dalam rak buku berdasarkan kategori buku tersebut, buku dikelompokkan menjadi 10 kategori buku setiap kategori diberikan penomoran yang disebut Dewey Decimal Classification (DDC). Selain itu, dalam penempatan letak buku belum diatur dengan melihat tingkat keseringan pengunjung membaca atau meminjam buku tersebut. Selain itu, pengunjung kesulitan dalam mencari keberadaan buku yang sering dibaca atau dipinjam karena letak buku yang dibutuhkan berada dirak yang berbeda-beda. Untuk mengatasi masalah tersebut, maka pada tugas akhir ini penulis akan mencari buku-buku yang sering dipinjam secara bersamaan oleh pengunjung dengan menganalisa data trasaksi peminjaman buku. Dengan mengetahui buku yang sering dipinjam secara bersamaan dapat mempermudah pustakawan dalam mengatur penempatan letak buku yang sesuai kebiasaan pengunjung dalam mencari buku yang dibutuhkan. Metode yang digunakan dalam tugas akhir ini adalah Association rule mining. Algoritma yang digunakan dalam penelitian ini adalah algoritma apriori. Algoritma apriori merupakan salah satu yang paling populer dalam pendekatan data mining untuk menemukan frequent itemset untuk aturan asosiasi boolean [2]. Penelitian ini bertujuan untuk mencari buku-buku yang sering dipinjam secara bersamaan pada tahun 2016-2018 dan perbulan untuk tempatkan secara berdekatan berdasarkan kategori buku. Algoritma Apriori telah berhasil dilakukan pada penelitian sebelumnya untuk menentukan hubungan antar item seperti: (1) 
pencarian aturan assosiasi pada data transaksi peminjaman buku perpustakaan [3];

(2) menemukan aturan assosiatif untuk memprediksi persedian buku dengan menganalisa data peminjaman buku [4]; (3) menentukan aturan assosiasi pada data peminjaman buku pada perpustakaan [5]; (4) untuk memperoleh informasi mengenai pola pembelian konsumen [6]. (5) mencari aturan assosiasi untuk meningkatkan kualitas produk dan penambahan jenis produk [7]

Berdasarkan penjelasan sebelumnya, maka Tugas akhir ini mengangkat judul "Penerapan Data Mining untuk menentukan penempatan buku di perpustakaan menggunakan Algoritma Apriori”..

\section{B. LANDASAN TEORI}

\section{B.1. KDD (Knowledge Discovery in Database)}

Knowledge Discovery in Database (KDD) didefenisikan sebagai ekstraksi informasi potensial, implisit dan tidak dikenal dari sekumpulan data. Proses Knowlegde Discovery in Database melibatkan hasil proses data mining (proses pengekstrak kecenderungan suatu pola data), kemudian mengubah hasilnya secara akurat menjadi informasi yang mudah dipahami [8]

Data mining juga sering disebut sebagai Knowledge Discovery in Database (KDD). KDD terdiri dari tiga proses utama yaitu [9]

1. Preprocessing

Preprocessing dilakukan terhadap data sebelum algoritma data mining diaplikasikan. Proses ini meliputi data cleaning, integrasi, seleksi dan transformasi.

\section{Data mining}

Proses utama dalam KDD adalah proses data mining, dalam proses ini algoritma-algoritma data mining diaplikasikan untuk mendapatkan pengetahuan dari sumber data.

\section{Post processing}

Hasil yang diperoleh dari proses data miningselanjutnya akan dievaluasi pada post processing.

\section{B.2. Data Mining}

Data Mining adalah proses yang memperkerjakan satu atau lebih teknik pembelajaran komputer (machine laerning) untuk menganalisis dan mengestraksi pengetahuan (knowledge) secara otomatis [10]. Data mining adalah suatu istilah yang digunakan untuk menguraikan penemuan pengetahuan didalam database. Data mining adalah proses yang menggunakan teknik statistik, matematika, kecerdasan buatan, dan machine learning untuk mengestraksi dan mengidentifikasi informasi yang bermanfaat dan pengetahuan yang terkait dari berbagai database besar [11]. Sebagai suatu rangkaian proses, data mining dapat dibagi menjadi beberapa tahap proses Tahap-Tahap Data Mining:

1. Pembersihan Data (data cleaning)

2. Integrasi Data (data integration)
3. Seleksi Data (data selection)

4. Transformasi Data (data transformation)

5. Proses Mining

6. Evaluasi Pola (pattern evaluation)

7. Presentasi pengetahuan (knowledge presentation)

\section{B.3. Assosiation Rule Mining}

Assocation rules mining adalah suatu metode yang digunakan untuk mencari hubungan antar item suatu dataset yang telah ditentukan . Association rules mining mencari dan menemukan hubungan antar item yang ada pada suatu dataset. Penerapan data mining dengan aturan assosiasi bertujuan menemukan informasi item-item yang seling berhubung dalam bentuk aturan/rule. Aturan asosisasi adalah teknik data mining untuk menemukan aturan assosiasi antar suatu kombinasi item [12]. Perhitungan nilai support dan confidence dapat dijelaskan sebagai berikut:

1. Analisa Pola Frekuensi Tinggi Support

Mencari Nilai support sebuah item diperoleh dengan menggunakan rumus berikut:

$\operatorname{Support}(\mathrm{A})=\frac{\sum \mathrm{Jumlah} \text { transaksi yang mengandung A }}{\sum \text { Total Transaksi }} \times 100$

Nilai support 2 item diperoleh dengan rumus:

Support $(\mathrm{A}, \mathrm{B})=\mathrm{P}(\mathrm{A} \cap \mathrm{B})$
Support $(\mathrm{A}, \mathrm{B})=\frac{\sum \mathrm{Jumlah} \text { transaksi yang mengandung } \mathrm{A} \text { dan } \mathrm{B}}{\sum \text { Total Transaksi }} \times 100$

2. Pembentukan Aturan Asosiasi Confidence

Pembentukan aturan asosiasi confidence diperoleh dengan rumus:

Confidence $(A, B)=\frac{\sum \text { Jumlah transaksi yang mengandung } A \text { dan } B}{\sum \text { Transaksi mengandung } A} \times 100$

\section{B.4. Algoritma Apriori}

Algoritma Apriori adalah suatu algoritma dasar yang diusulkan oleh Agrawal \& Srikant pada tahun 1994 untuk penentuan frequent itemset untuk aturan asosiasi boolean. Algoritma apriori termasuk jenis aturan asosiasi pada Data Mining. Aturan yang menyatakan asosiasi antara beberapa atribut sering disebut Affinity Analysis atau MBA [8]. Untuk penerapan Algoritma Apriori, secara umum dibutuhkan struktur data untuk menyimpan candidate frequent itemset untuk suatu iterasi ke $\mathrm{k}$ dan untuk menyimpan frequent itemset yang dihasilkan. Ketika membaca tiap item dari seluruh transaksi, selain mendapatkan item-item baru juga dilakukan perhitungan nilai support item-item yang sudah ditemukan, sehingga untuk mendapatkan candidate 1-itemset beserta nilai support-nya cukup membutuhkan satu kali pembacaan data [13].

\section{B.5. Buku}

Menurut Tarigan dan Tarigan 2009:13 dalam (Dhinata dkk., 2016), Buku teks adalah buku pelajaran dalam bidang studi tertentu yang 
merupakan buku standar, yang disusun oleh para pakar dalam bidang itu buat maksud-maksud dan tujuan instruksional, yang melengkapi dengan sarana-sarana pengajaran yang serasi dan mudah dipahami oleh para pemakainya di sekolah-sekolah dan pergururan tinggi, sehingga dapat menunjang suatu proses pengajaran. [14].

\section{B.6. Perpustakaan}

Perpustakaan dapat dirumuskan sebagai unit kerja dari sebuah lembaga pendidikan yang berupa tempat penyimpanan koleksi buku-buku pustaka untuk menunjang proses pendidikan. Perpustakaan didefinisikan sebagai gedung yang memiliki koleksi bahan pustaka (buku, majalah dan media lainnya) yang ditata atau diatur dengan cara tertentu agar mudah dimanfaatkan oleh pengguna secara cepat dan tepat [1].

\section{B.7. Rapid Miner}

Rapid Miner merupakan perangkat lunak yang dibuat oleh Dr. Markus Hofmann dari Institute of Technologi Blanchardstown dan Ralf Klinkenberg dari rapid-i.com dengan tampilan GUI (Graphical User Interface) sehingga memudahkan pengguna dalam menggunakan perangkat lunak ini. RapidMiner merupakan perangakat lunak yang bersifat terbuka (open source). RapidMiner adalah sebuah solusi untuk melakukan analisis terhadap data mining, text mining dan analisis prediksi. RapidMiner menggunakan berbagai teknik deskriptif dan prediksi dalam memberikan wawasan kepada pengguna sehingga dapat membuat keputusan yang paling baik.

\section{METODOLOGI PENELITIAN}

Adapun alur Tugas akhir ini dijelaskan dalam metode penlitian seperti pada gambar dibawah ini.

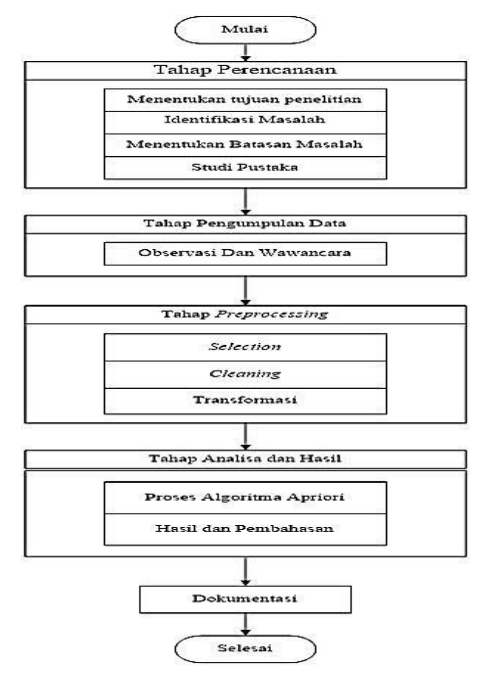

Gambar 1. Metode Penelitian

\section{C.1. Tahap Perencanaan}

Tahap perencanaan adalah tahap pertama sebelum melakukan penelitian. Tahap perencanaan terdiri dari empat perencanaan yaitu:
1. Menentukan Tujuan Penelitian

2. Identifikasi Masalah

3. Menentukan Batasan Masalah

4. Studi Pustaka

\section{C.2. Tahap Pengumpulan Data}

Dalam tahap pengumpulan data dilakukan dengan dua cara yaitu observasi dan wawancara. Dalam penelitian ini penulis melakukan pengumpulan data dengan meneliti langsung ke lapangan untuk mendapatkan data dari sumber informasi yang akurat terkait dengan masalah yang akan diteliti. Dari hasil wawancara diperoleh permasalahan proses penempatan/tata letak buku yang terjadi diperpustakaan dan data transaksi peminjaman buku pada tahun 2016-2018 sebanyak 67.356 .

\section{C.3. Tahap Preprocessing Data}

Dalam tahap praprocessing ini terdapat tiga tahapan yang akan dilalui sebagai berikut:
1. Data Selection
2. Data Cleaning
3. Transformasi Data

\section{C.4. Tahap Analisa dan Hasil}

Setelah semua data terkumpul selanjutnya dilakukan tahap analisa. Adapun kegiatan yang dilakukan pada tahap ini adalah:

1. Proses Algoritma Apriori

Proses Algoritma Apriori dilakukan menggunakan aplikasi alat bantu Rapid Miner 9.0, minimal support dan confidance ditentukan dengan cara membangdingkan nilai support dan cofidance dari yang tertinggi hingga yang terendah sehingga didapatkan nilai support dan confidance yang efektif dan memiliki aturan assosiasi yang kuat. Proses analisis menggunakan algortima apriori terbagi menjadi dua tahap yaitu melakukan analisa pola frekuensi tinggi dan pembentukan aturan assosiatif (association rule).

2. Hasil dan Pembahasan

Hasil dan pembahasan dalam penelitian tugas akhir berbentuk informasi yang dihasilkan dari proses apriori. Informasi yang dihasilkan berupa asosiasi pola peminjaman buku yang sering dipinjam oleh pengunjung secara bersamaan. Hasil dari aturan asosiasi ini dapat digunakan untuk penentuan penempatan tata letak buku yang dipinjam secara bersamaan ditempatkan secara berdekatan.

\section{C.5. Tahap Dokumentasi}

Tahap dokumentasi dilakukan dari awal penelitian hingga akhir penelitian. Hasil akhir dari proses dokumentasi berupa laporan tugas akhir yang nantinya akan diuji kembali dihadapan pemimbing dan penguji. Untuk mendapatkan hasil yang baik dalam penulisan laporan dilakukan studi pustaka dan konsultasi dengan pemimbing tugas akhir. 


\section{HASIL DAN PEMBAHASAN}

D.1. Pengumpulan data Knowledge Discovery in Database (KDD)

Data transaksi peminjaman buku yang terkumpul adalah 67.356 transaksi. Setalah praproses data menjadi 11.550 transaksi. Data transaksi peminjaman buku data dilihat pada tabel 1 . Dapat dilihat pada tabel 1.

Tabel 1 Data transaksi Peminjaman Buku 20162018.

\begin{tabular}{|c|c|c|}
\hline No & Tanggal & Transaksi \\
\hline 1 & Jan-2-2016 & Filsafat, Teknologi \\
\hline 2 & Jan-2-2016 & Sastra, Sejarah \\
\hline 4 & Feb-1-2016 & Sastra, Sejarah \\
\hline 5 & Feb-1-2016 & Teknologi, Sastra \\
\hline$\ldots$ & …........... & …................ \\
\hline 11546 & Des-26-2018 & filsafat, ilmu sosial \\
\hline 11547 & Des-26-2018 & agama, ilmu sosial \\
\hline 11548 & Des-26-2018 & ilmu sosial, sastra \\
\hline 11549 & Des-26-2018 & karya umum, bahasa \\
\hline 11550 & Des-26-2018 & filsafat, agama \\
\hline
\end{tabular}

Tabel 2 Boolean Data Transaksi peminjaman buku 2016-2018

\begin{tabular}{|c|c|c|c|c|c|c|c|c|c|c|}
\hline \multicolumn{11}{|c|}{ 2016-2018 } \\
\hline 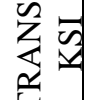 & $\vec{v}$ & 㫐 & $\cong$ & $\underset{\&}{U}$ & 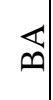 & $\Sigma$ & $\stackrel{\bullet}{\bullet}$ & $\stackrel{\vartheta}{\triangleleft}$ & 5 & $\bar{s}$ \\
\hline 1 & 0 & 1 & 0 & 0 & 0 & 0 & 1 & 0 & 0 & 0 \\
\hline 2 & 0 & 0 & 0 & 0 & 0 & 0 & 0 & 0 & 1 & 1 \\
\hline 3 & 0 & 0 & 0 & 0 & 0 & 0 & 0 & 1 & 1 & 0 \\
\hline 4 & 1 & 0 & 0 & 0 & 0 & 0 & 1 & 0 & 0 & 0 \\
\hline 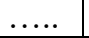 & & 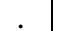 & .. & $\ldots$ &.. & $\ldots$ & $\ldots$ & $\ldots$ &. & \\
\hline $\begin{array}{c}115 \\
47\end{array}$ & 0 & 0 & 1 & 1 & 0 & 0 & 0 & 0 & 0 & 0 \\
\hline $\begin{array}{c}115 \\
48\end{array}$ & 0 & 0 & 0 & 1 & 0 & 0 & 0 & 0 & 1 & 0 \\
\hline $\begin{array}{c}115 \\
49\end{array}$ & 1 & 0 & 0 & 0 & 1 & 0 & 0 & 0 & 0 & 0 \\
\hline $\begin{array}{c}115 \\
50\end{array}$ & 0 & 1 & 1 & 0 & 0 & 0 & 0 & 0 & 0 & 0 \\
\hline
\end{tabular}

\section{D.2. Proses Algoritma Apriori}

Pada tahap ini data yang telah terkumpul diolah melalui praproses data yang digunakan untuk proses Algoritma Apriori ini adalah data transaksi pada tabel 1. Tahap selanjutnya melakukan percobaan perhitungan secara manual. Dalam percobaan perhitungan secara manual ini menggunakan 50 data sampel dikarenakan proses yang sangat memakan waktu yang lama dan panjang, dengan demikian untuk pengelolaan data secara keseluruhan menggunakan tools Rapid Miner 9.0. Adapun tujuan perhitungan manual ini adalah untuk menjelaskan secara detail bagaimana proses dalam algoritma yang digunakan. Data yang digunakan dapat dilihat pada tabel 1.

Tabel 3 Data Sampel Transaksi Peminjaman Buku

\begin{tabular}{|c|c|c|}
\hline No & Tanggal & Transaksi \\
\hline 1 & Jan-5-2016 & Karya Umum, Agama \\
\hline 2 & Jan-5-2016 & Ilmu Sosial, Ilmu Murni \\
\hline 3 & Jan-5-2016 & Ilmu Sosial, Ilmu Murni \\
\hline 4 & Jan-6-2016 & Karya Umum, Teknologi \\
\hline 5 & Jan-6-2016 & Bahasa, Sastra \\
\hline$\cdots$ & $\ldots \ldots \ldots+\cdots \cdots$ & 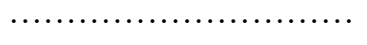 \\
\hline 46 & Jan-9-2016 & Agama, Ilmu Sosial \\
\hline 47 & Jan-9-2016 & Agama, Ilmu Sosial \\
\hline 48 & Jan-9-2016 & Ilmu Sosial, Ilmu Murni \\
\hline 49 & Jan-9-2016 & Karya Umum, Teknologi \\
\hline 50 & Jan-9-2016 & $\begin{array}{l}\text { Karya Umum, Ilmu } \\
\text { Sosial }\end{array}$ \\
\hline
\end{tabular}

\section{Analisa Pola Frekuensi Tinggi}

Tahap ini mencari 1 item yang memenuhi syarat minimum dari nilai support dalam basis data. Salah satu contoh mencari nilai nilai support item adalah sebagai berikut:

Support $($ Ilmu Sosial $)=\frac{25}{50} \times 100 \%=50 \%$

Untuk lebih jelas hasil perhitungan support padat transaksi peminjaman buku dapat dilihat pada Tabel 4:

Tabel 4 Daftar Nilai Support Item Katgeori Buku Nilai Minimum Support 5\%.

\begin{tabular}{|l|l|l|}
\hline Kategori Buku & Jumlah & Support \\
\hline Ilmu Sosial & 25 & $50 \%$ \\
\hline Agama & 20 & $40 \%$ \\
\hline Teknologi & 14 & $28 \%$ \\
\hline
\end{tabular}




\begin{tabular}{|l|l|l|}
\hline Karya Umum & 11 & $22 \%$ \\
\hline Filsafat & 8 & $16 \%$ \\
\hline Bahasa & 7 & $14 \%$ \\
\hline Ilmu Murni & 7 & $14 \%$ \\
\hline Sastra & 6 & $12 \%$ \\
\hline Sejarah & 2 & $4 \%$ \\
\hline Kesenia/Olahraga & 1 & $2 \%$ \\
\hline
\end{tabular}

Tabel 5 Daftar nilai support 1 item set calon kombinasi 2 item set.

\begin{tabular}{|l|l|l|}
\hline Kategori Buku & Jumlah & Support \\
\hline Ilmu Sosial & 25 & $50 \%$ \\
\hline Agama & 20 & $40 \%$ \\
\hline Teknologi & 14 & $28 \%$ \\
\hline Karya Umum & 11 & $22 \%$ \\
\hline Filsafat & 8 & $16 \%$ \\
\hline Bahasa & 7 & $14 \%$ \\
\hline Ilmu Murni & 7 & $14 \%$ \\
\hline Sastra & 6 & 12 \\
\hline
\end{tabular}

\section{Pembentukan Pola Kombinasi Dua Item}

Pembentukan pola frekuensi dua item, dibentuk dari item yang memenuhi support minimal yaitu dengan cara mengkombinasi semua item kedalam dua kombinasi item. Berikut ini merupakan penyelesaian perhitungan support kombinasi dua item set dengan jumlah minimum support $5 \%$. Salah satu contoh mencari nilai support kombinasi item adalah sebagai berikut:

Support $(K U, A G)=\frac{3}{50} \times 100 \%=6 \%$

Hasil pembentukan pola kombinasi dua itemset

Tabel 6 Nilai support kombinasi 2 item buku.

\begin{tabular}{|l|l|l|}
\hline Kategori Buku & Jumlah & Support \\
\hline $\begin{array}{l}\text { Karya Umum } \\
\text { dan Agama }\end{array}$ & 3 & $6 \%$ \\
\hline $\begin{array}{l}\text { Karya Umum } \\
\text { dan Ilmu Sosial }\end{array}$ & 3 & $6 \%$ \\
\hline $\begin{array}{l}\text { Karya Umum } \\
\text { dan Teknologi }\end{array}$ & 3 & $6 \%$ \\
\hline $\begin{array}{l}\text { Filsafat dan Ilmu } \\
\text { Sosial }\end{array}$ & 3 & $6 \%$ \\
\hline
\end{tabular}

\begin{tabular}{|l|l|l|}
\hline $\begin{array}{l}\text { Agama dan Ilmu } \\
\text { Sosial }\end{array}$ & 10 & $20 \%$ \\
\hline $\begin{array}{l}\text { Agama dan } \\
\text { Teknologi }\end{array}$ & 4 & $8 \%$ \\
\hline $\begin{array}{l}\text { Ilmu Sosial dan } \\
\text { Ilmu Murni }\end{array}$ & 4 & $8 \%$ \\
\hline $\begin{array}{l}\text { Ilmu Sosial dan } \\
\text { Teknologi }\end{array}$ & 4 & $6 \%$ \\
\hline $\begin{array}{l}\text { Bahasa dan } \\
\text { Teknologi }\end{array}$ & 3 & 6 \\
\hline
\end{tabular}

\section{Pembentukan Pola Aturan Asosiasi}

Setelah semua pola frekuensi tinggi ditemukan, baru dicari aturan asosiasi yang memenuhi syarat minimum untuk confidence dengan menghitung confidence A ke B. Salah satu contoh mencari nilai confidence kombinasi 2 item adalah sebagai berikut:

Confidence $(\mathrm{KU}, \mathrm{FT})=\frac{1}{11} \times 100 \%=9,09 \%$

Confidence $(\mathrm{FT}, \mathrm{KU})=\frac{1}{8} \times 100 \%=12,5 \%$

Berikut hasil pembentukan pola aturan asosiasi dapat dilihat pada tabel 7.

Tabel 7 Daftar nilai confidence kombinasi 2 item kategori buku.

\begin{tabular}{|l|l|l|}
\hline $\begin{array}{l}\text { Kombinasi 2 } \\
\text { item buku }\end{array}$ & $38 \%$ \\
\hline $\begin{array}{l}\text { Filsafat dan Ilmu } \\
\text { Sosial }\end{array}$ & $3 / 8$ & $50 \%$ \\
\hline $\begin{array}{l}\text { Agama dan Ilmu } \\
\text { Sosial }\end{array}$ & $10 / 20$ & $57,14 \%$ \\
\hline $\begin{array}{l}\text { Ilmu Sosial dan } \\
\text { Ilmu Murni }\end{array}$ & $4 / 25$ & $50 \%$ \\
\hline $\begin{array}{l}\text { Bahasa dan } \\
\text { Sastra }\end{array}$ & $3 / 7$ & \\
\hline
\end{tabular}

Aturan asosiasi tersebut dapat dilihat pada Tabel 4.30.

Tabel 8 Hasil Association Rule

\begin{tabular}{|l|l|l|l|}
\hline \multicolumn{2}{|l|}{$\begin{array}{l}\text { Antecendent and } \\
\text { consequent }\end{array}$} & \multirow{2}{*}{ Support } & \multirow{2}{*}{ Confidence } \\
\cline { 1 - 3 } Jika & Maka & & \\
\hline Filsafat & $\begin{array}{l}\text { Ilmu } \\
\text { Sosial }\end{array}$ & $6 \%$ & $38 \%$ \\
\hline Agama & $\begin{array}{l}\text { Ilmu } \\
\text { Sosial }\end{array}$ & $20 \%$ & $50 \%$ \\
\hline
\end{tabular}


Jurnal Ilmiah Rekayasa dan Manajemen Sistem Informasi, Vol. 5, No. 1, Februari 2019, Hal. 99-108 e-ISSN 2502-8995 p-ISSN 2460-8181

\begin{tabular}{|l|l|l|l|}
\hline $\begin{array}{l}\text { Ilmu } \\
\text { Sosial }\end{array}$ & $\begin{array}{l}\text { Ilmu } \\
\text { Murni }\end{array}$ & $8 \%$ & $57,14 \%$ \\
\hline Bahasa & Sastra & $6 \%$ & $50 \%$ \\
\hline
\end{tabular}

Berikut penjelasan dari rule pada tabel 8 .

1. Jika pengunjung meminjam buku dengan kategori filsafat maka pengunjung akan meminjam buku dengan kategori ilmu sosial dengan tingakat kepercayaan $38 \%$ dan didukung $6 \%$ dari data keseluruhan.

2. Jika pengunjung meminjam buku dengan kategori agama maka pengunjung akan meminjam buku dengan kategori ilmu sosial dengan tingakat kepercayaan 50\% dan didukung $20 \%$ dari data keseluruhan.

3. Jika pengunjung meminjam buku dengan kategori ilmu sosial maka pengunjung akan meminjam buku dengan kategori ilmu murni dengan tingakat kepercayaan $57,14 \%$ dan didukung $8 \%$ dari data keseluruhan.

4. Jika pengunjung meminjam buku dengan kategori bahasa maka pengunjung akan meminjam buku dengan kategori sastra dengan tingakat kepercayaan 50\% dan didukung $6 \%$ dari data keseluruhan.

\section{E. Penerapan Algoritma Apriori Pada Semua} Data Tahun 2016-2018

Pada tahap ini, data transaksi peminjaman buku selama 3 tahun diolah menggunakan bantuan tools Rapid Miner 9.0. Untuk menentukan nilai support dan confidence peneliti melakukan percobaan terhadap data keseluruhan dengan nilai support dan confidence berbeda mulai dari nilai support tertinggi dan nilai confidence terendah, sehinggah ditemukan nilai support dan confidence yang efektif .

\section{E.1 Tahap Pencarian Nilai Support dan Confidence}

Pada tahap pengujian, peneliti melakukan pengujian semua data yang didapatkan selama 3 tahun dengan nilai minimum support $5 \%, 10 \%$, dam $15 \%$, sedangkan untuk minimum confidence dengan nilai $20 \%, 30 \%$, dan $40 \%$. Tujuan dilakukannya pengujian dengan nilai support dan confidence yang berbeda unuk menentukan nilai minimum support dan confidence yang efektif yang ada pada data peminjaman buku di Perpustakaan Soeman Hs. Pengujian dilakukan sebnayak 9 kali dengan nilai support dan confidence yang berbeda disetiap pengujiannya sesusai dengan nilai support dan confidence yang telah ditentukan.

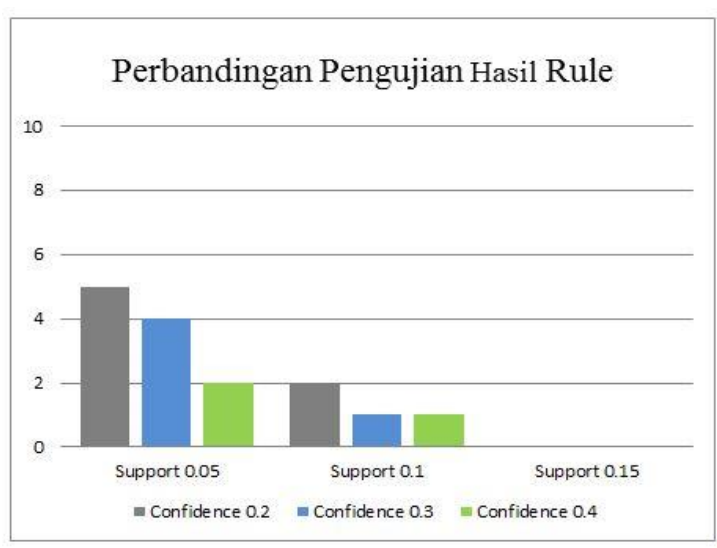

Gambar 2. Grafik Hasil Pengujian Perbandingan Rule.

Berdasarkan pengujian diatas, dapat dilihat bahwa nilai support $15 \%$ dan confidence $20 \%$, $30 \%$, dan $50 \%$ tidak efektif untuk analisis karena minimum support dan aturan asosiasi yang dihasilkan tidak memenuhi acuan yang telah ditentukan, dalam hal ini peneliti menentukan nilai support yang efektif adalah minimum support $5 \%$ dan minimum confidence $30 \%$. Hasil analisis pengujian menunjukkan bahwa dengan minimum support $5 \%$ dan minimum confidence $30 \%$ rule yang dihasilkan pada hampir sama. Selain itu, dilihat dari hasil rule yang didapatkan dengan nilai confidence $20 \%$ dan $40 \%$ tetap setiap percobaan, maka dapat disimpulkan bahwa nilai tersebut tidak mempengaruhi terhadap hasil yang didapatkan pada analisa data transaksi peminjaman buku. Dan untuk nilai support $5 \%$ memiliki tingkat aturan asosiasi yang kuat dibanding dengan nilai support $10 \%$ dan $15 \%$. Dengan demikian nilai minimum support dan minimum confidence yang efektif untuk data transaksi peminjaman buku di Perpustakaan Soeman Hs adalah $5 \%$ dan $30 \%$.

\section{D.4 Tahap Analisa Hasil Semua Data Pada Tahun 2016-2018}

Tahap analisa hasil rule yang didapatkan dari nilai support dan confidence yang didapatkan sebeleunya terhadap semua data sebanyak 11550 dengan nilai support 5\% dan confidence $30 \%$. Berikut hasil analisa dari hasil rule yang didapatkan dapat dilihat pada Gambar 3.

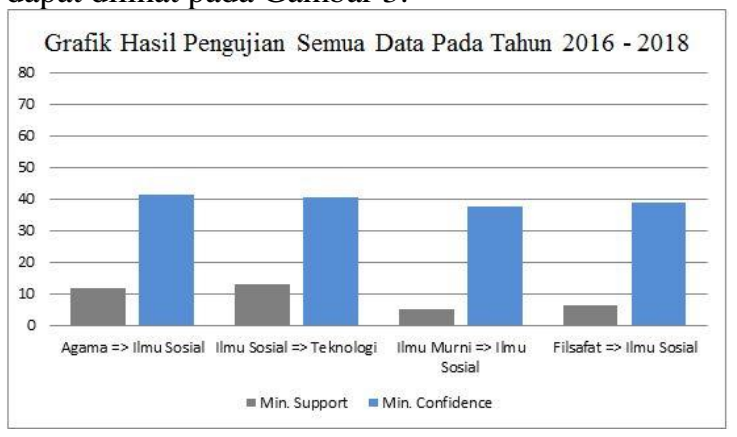

Gambar 3. Grafik Hasil Pengujian Pada Semua Data Pada Tahun 2016-2018

D.5 Tahap Analisa Hasil Bulan Januari 20162018 
Tahap analisa pada data Bulan Januari dengan jumlah data sebanyak 955 dengan minimum support $5 \%$ dan minimum confidence $30 \%$. Hasil pengujian data Bulan Januari 2016-2018 dapat dilihat pada Gambar 4 dibawah ini.

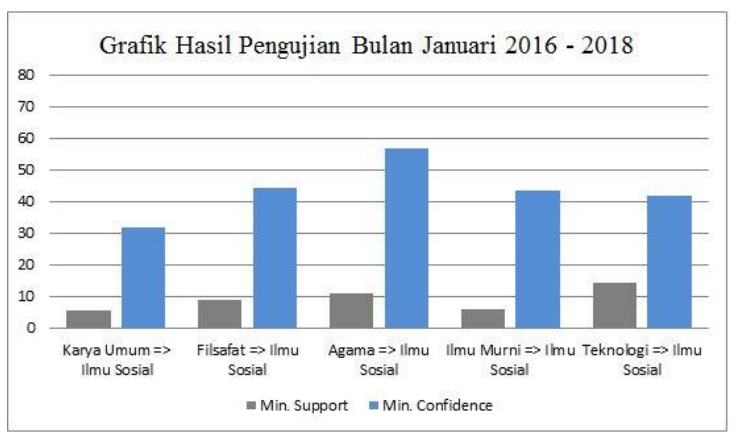

Gambar 4. Grafik Hasil Pengujian Pada Data Bulan Januari 2016-2018

\section{D.6 Tahap Analisa Hasil Bulan Februari 2016- 2018}

Tahap analisa pada data Bulan Februari dengan jumlah data sebanyak 1219 dengan minimum support $5 \%$ dan minimum confidence $30 \%$. Hasil pengujian data Bulan Januari dapat dilihat pada Gambar 5 dibawah ini.

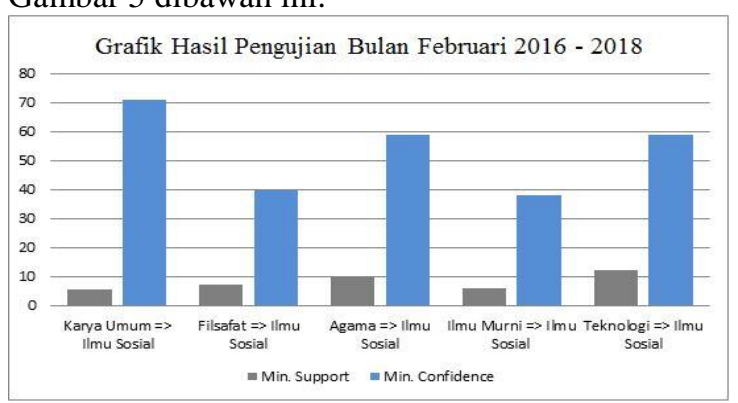

Gambar 5. Grafik Hasil Pengujian Pada Data Bulan Februari 2016-2018

D.7 Tahap Analisa Hasil Bulan Maret 20162018

Tahap analisa pada data Bulan Maret dengan jumlah data sebanyak 1631 dengan minimum support $5 \%$ dan minimum confidence $30 \%$. Hasil pengujian data Bulan Maret 2016-2018 dapat dilihat pada Gambar 6 dibawah ini.

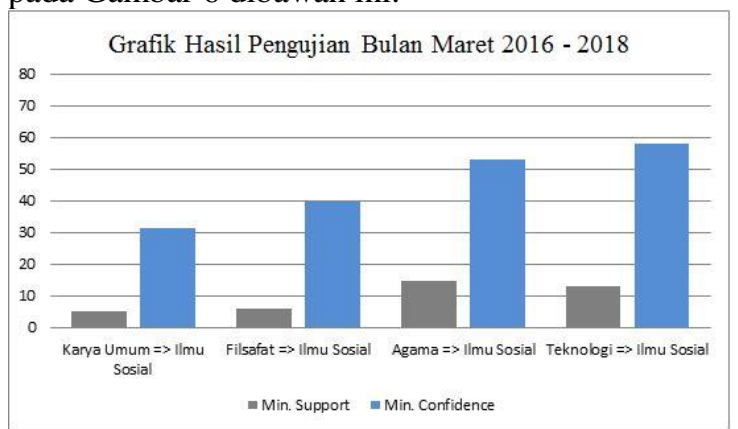

Gambar 6. Grafik Hasil Pengujian Pada Data Bulan Maret 2016-2018

D.8 Tahap Analisa Hasil Bulan April 2016-2018

Tahap analisa pada data Bulan April dengan jumlah data sebanyak 1278 dengan minimum support 5\% dan minimum confidence $30 \%$. Hasil pengujian data Bulan April 2016-2018 dapat dilihat pada Gambar 7 dibawah ini.

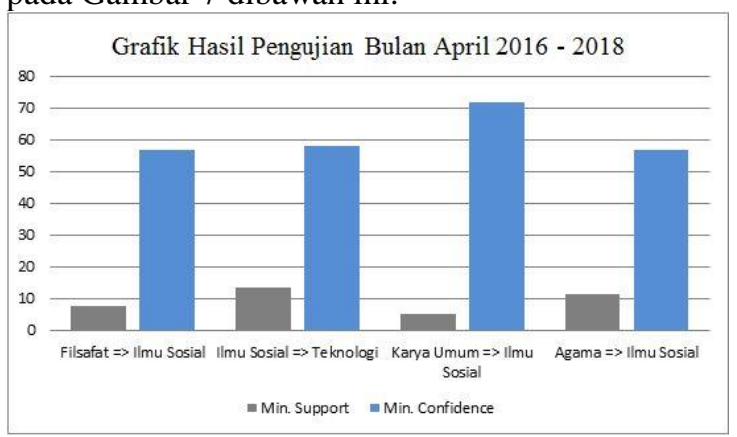

Gambar 7. Grafik Hasil Pengujian Pada Data Bulan April 2016-2018

D.9 Tahap Analisa Hasil Bulan Mei 2016-2018

Tahap analisa pada data Bulan Mei dengan jumlah data sebanyak 860 dengan minimum support $5 \%$ dan minimum confidence $30 \%$. Hasil pengujian data Bulan Mei dapat dilihat pada Gambar 8 dibawah ini.

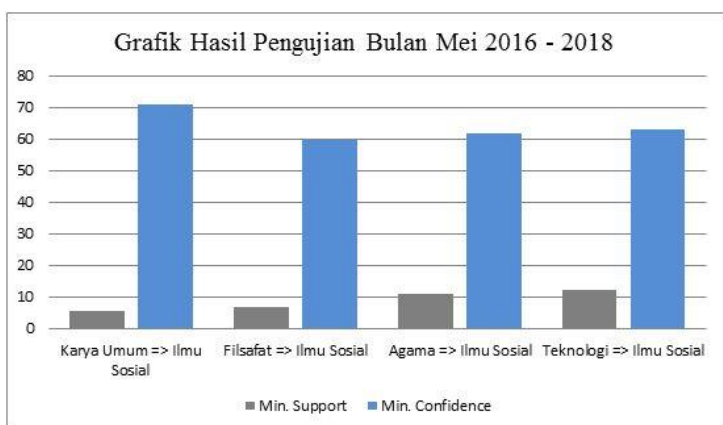

Gambar 8. Grafik Hasil Pengujian Pada Data Bulan Mei 2016-2018

\section{D.10 Tahap Analisa Hasil Bulan Juni 2016-2018}

Tahap analisa pada data Bulan Juni dengan jumlah data sebanyak 386 dengan minimum support $5 \%$ dan minimum confidence $30 \%$. Hasil pengujian data Bulan Juni 2016-2018 dapat dilihat pada Gambar 9 dibawah ini.

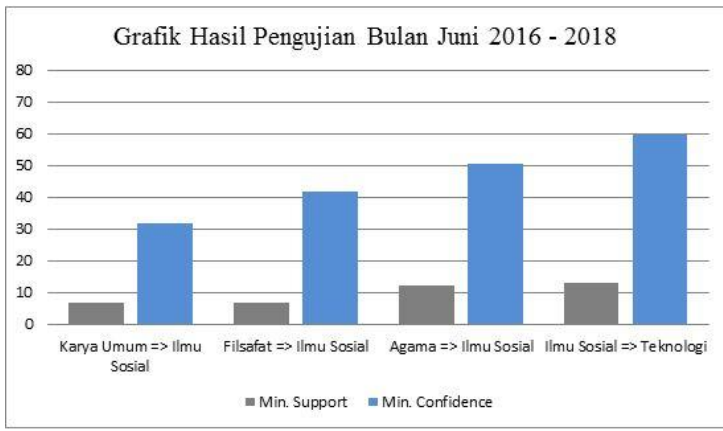

Gambar 9. Grafik Hasil Pengujian Pada Data Bulan Juni 2016-2018

\section{D.11 Tahap Analisa Hasil Bulan Juli 2016-2018}

Tahap analisa pada data Bulan Juli dengan jumlah data sebanyak 442 dengan minimum support $5 \%$ dan minimum confidence $30 \%$. Hasil pengujian 
data Bulan Juli dapat dilihat pada Gambar 10 dibawah ini.

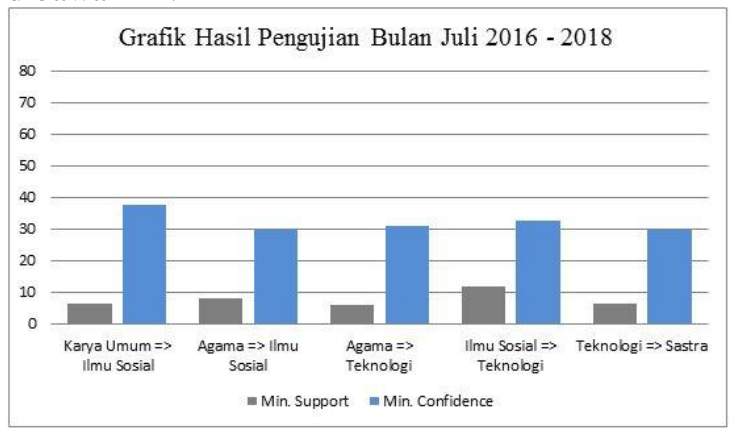

Gambar 10. Grafik Hasil Pengujian Pada Data Bulan Juli 2016-2018

D.12 Tahap Analisa Hasil Bulan Agustus 20162018

Tahap analisa pada data Bulan Agustus dengan jumlah data sebanyak 583 dengan minimum support $5 \%$ dan minimum confidence $30 \%$. Hasil pengujian data Bulan Agustus 2016-2018 dapat dilihat pada Gambar 11 dibawah ini.

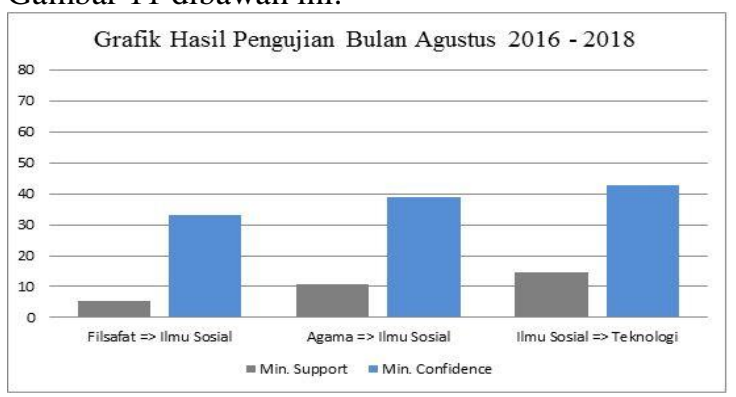

Gambar 11. Grafik Hasil Pengujian Pada Data Bulan Agustus 2016-2018

\section{D.13 Tahap Analisa Hasil Bulan September 2016- 2018}

Tahap analisa pada data Bulan September dengan jumlah data sebanyak 1038 dengan minimum support 5\% dan minimum confidence $30 \%$. Hasil pengujian data Bulan September 2016-2018 dapat dilihat pada Gambar 12 dibawah ini.

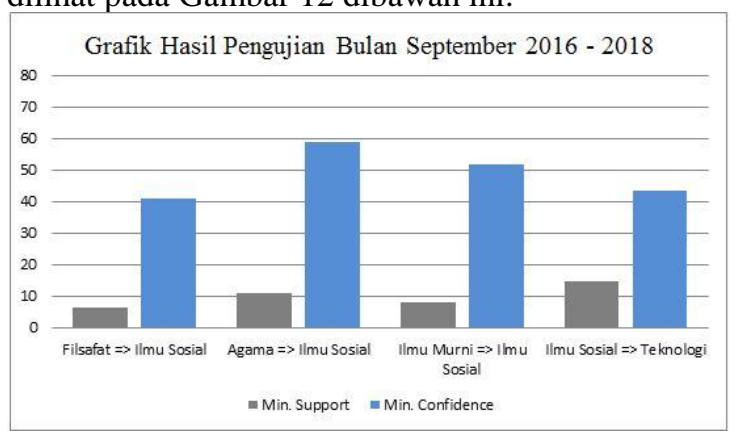

Gambar 12. Grafik Hasil Pengujian Pada Data Bulan September 2016-2018

\section{D.14 Tahap Analisa Hasil Bulan Oktober 2016- 2018}

Tahap analisa pada data Bulan Oktober dengan jumlah data sebanyak 1348 dengan minimum support $5 \%$ dan minimum confidence $30 \%$. Hasil pengujian data Bulan Oktober 2016-2018 dapat dilihat pada Gambar 13 dibawah ini.

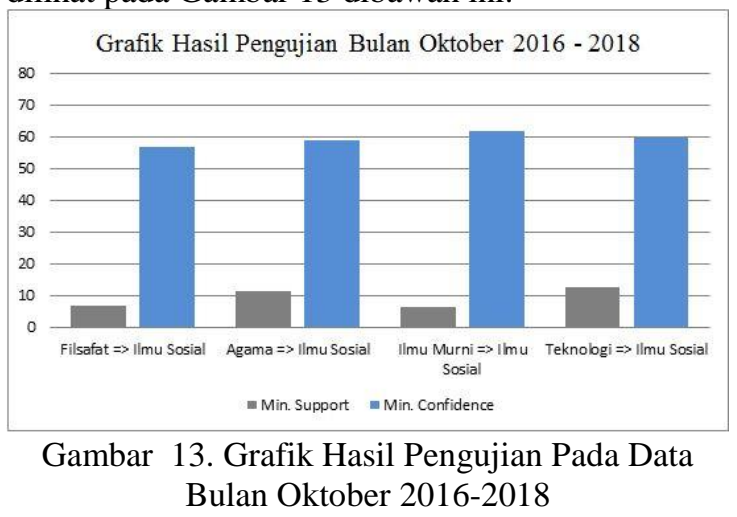

D.15 Tahap Analisa Hasil Bulan November 20162018

Tahap analisa pada data Bulan November dengan jumlah data sebanyak 1035 dengan minimum support $5 \%$ dan minimum confidence $30 \%$. Hasil pengujian data Bulan November 2016-2018 dapat dilihat pada Gambar 14 dibawah ini.

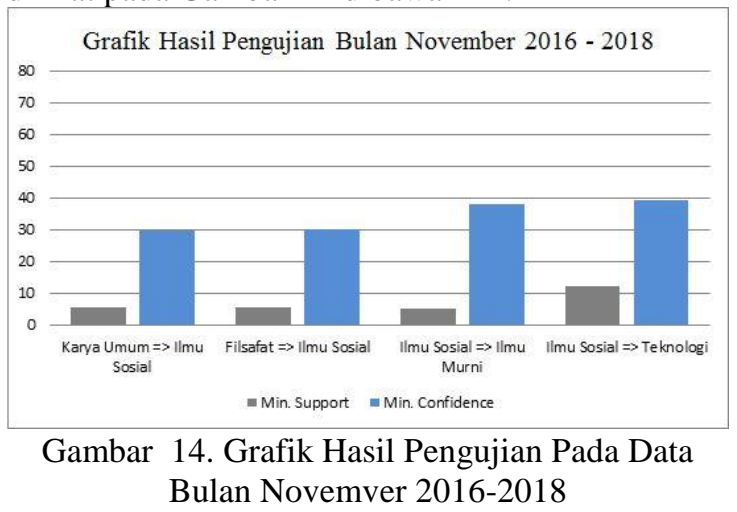

D.16 Tahap Analisa Hasil Bulan Desember 20162018

Tahap analisa pada data Bulan Desember dengan jumlah data sebanyak 775 dengan minimum support 5\% dan minimum confidence 30\%. Hasil pengujian data Bulan Desember 2016-2018 dapat dilihat pada Gambar 15 dibawah ini.

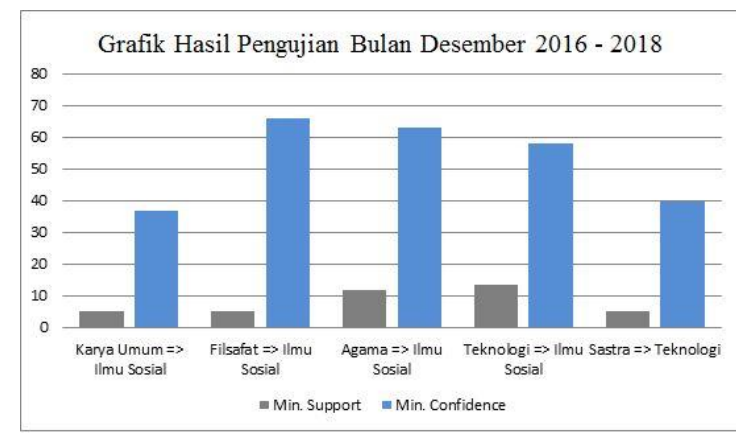

Gambar 15. Grafik Hasil Pengujian Pada Data Bulan Desember 2016-2018

E. Penutup

E.1 Kesimpulan

Berdasarkan hasil proses Algoritma Apriori pada data transaksi peminjaman buku di 
Perpustakaan Soemanh Hs Provinsi Riau dapat disimpulkan.

1. Penelitian ini berhasil menganalisa data transaksi peminjaman buku untuk mengetahui buku-buku yang sering dipinjam secara bersamaan menggunakan algoritma Apriori. Hasil dari analisa pada semua data transaksi peminjaman buku dari tahun 2016-2018 dapat disimpulkan bahwa jika pengunjung meminjam buku dengan kategori buku agama maka akan meminjam buku dengan kategori buku ilmu sosial aturan ini memilik nilai support $11,71 \%$ dan confidence $41,43 \%$ dan jika pengunjung meminjam buku dengan kategori buku teknologi maka akan meminjam buku dengan kategori buku ilmu sosial aturan ini memiliki nilai support $13,8 \%$ dan confidence $40,75 \%$.

2. Hasil dari analisa data transaksi peminjaman buku perbulan dari tahun 20162018 dapat disimpulkan bahwa jika pengunjung meminjam buku dengan kategori buku agama maka akan meminjam buku dengan kategori buku ilmu sosial aturan ini memilkik nilai support $9,10 \%$ dan confidence $44,61 \%$. Selain itu jika pengunjung meminjam buku denga kategori buku filsafat maka akan meminjam buku dengan kategori buku ilmu sosial aturan ini memiliki nilai support $12 \%$ dan confidence $63 \%$. Dan jika pengunjung meminjam buku dengan kategori buku teknologi maka akan meminjam buku dengan kategori buku ilmu sosial aturan ini memiliki nilai $12,53 \%$ dan confidence $60 \%$.

3. Denga hasil analisa pada semua data dan perbulan dari tahun 2016-2018 didapatkan buku dengan kategori buku agama, teknologi, filsafat dan ilmu sosial paling sering dipinjam secara bersamaan. Dengan hasil ini disarankan pada pihak pustakawan perpustakaan Soeman Hs untuk menempatkan letak kategori buku tersebut pada rak yang berdekatan. Selain itu pihak pustakawan bisa memberikan rekomendasi kepada pengunjung yang meminjam buku dengan kategori buku agama, filsafat, teknologi agar meminjam juga meminjam buku dengan kategori buku ilmu sosial.

F. Saran

Adapun saran yang dapat diberikan untuk penelitian selanjutnya adalah:

1. Menggunakan algoritma Association Rule Mining lainnya seperti FP Growth dan Rough set atau mengabungkan beberapa metode lainnya untuk mendapatkan hasil yang optimal 2. Untuk peneliti selanjutnya diharapakan melanjutkan penelitian ini apakah buku yang sering dipinjam secara bersamaan ditempatkan secara berdekatan berpengaruh terhadap meningkatnya minat baca pengunjung dip;[p[perpustakaan Soeman Hs.

\section{REFERENSI}

[1] Undang-undang RI. No. 43 Tahun 2007

tentang perpustakaan.

[2] Yanto, Robi., dan Khomariah, Riri, "Implementasi Data Mining dengan Metode Algoritma Apriori dalam Menentukan Pola Pembelian Obat", Citiec Journal, Februari 2015.

[3] Srikanti, Esis., Yansi, Rizka Fitri., Norhavina., Permana, Inggih dan Salisah, Febi Nur. "Penerapan Algoritma Apriori untuk Mencari Aturan Asosiasi pada Data Peminjaman Buku di Perpustakaan" Jurnal Ilmiaah Rekayasa dan Manejemen Sistem Informsi. 3(1): 77-80. 2018. 4]

[4] Lingga, Domma. 2016. Penerapan Algoritma Apriori dalam Meprediksi Persediaan Buku pada Perpustakaan SMA Dwi Tunggal Tanjung Morawa. Majalah Ilmiah Informasi dan Teknologi Ilmia. 11 (1): 18-22.

[5] Rapita Sari. (2018). "Implementasi Algoritma Apriori Pada Data Mining Untuk Pola Peminjaman Buku di Perpustakaan Uin Raden Fatah Palembang". Skripsi. Bogor: Fakultas Sains dan Teknologi. Universitas Islam Negeri Raden Fatah Palembang.

[6] M.Iqbal. (2018). "Market Bakset Analysis Pada Sentral Koleksi Indonesia Menggunakan Algoritma Apriori”. Skripsi. Pekanbaru: Fakultas Sains dan Teknologi. Universitas Islam Negeri Sultan Syarif Kasim Riau.

[7] Hernawati. (2018). Analisis Market Basket dengan Algoritma Apriori (Studi Kasus: Toko Alief). Ikraith-Informatika. Vol. 2. No. 1: 13-17.

[8] Tampubolon, Kennedi., Saragih, Hoga., dan Bobby Reza, "Implementasi Data Mining Algoritma Apriori Pada Sistem Persediaan Alat-Alat Kesehatan”, Majalah Ilmiah Informasi dan Teknologi Ilmiah (INTI), Vol. I, No. 1, Oktober 2013.

[9] Kurniawati, Anis, "Pemetaan Pola Hubungan Program Studi dengan Algoritma Apriori Studi Kasus SPMU UNNES”, Edu Komputika Journal 1 (1) (2014).

[10] Hermawati FA, 2013. Data Mining. Yogyakarta.

[11] Nursikuwagus, A., \& Hartono, T. (2016). Implementasi Algoritma Apriori Untuk Analisis Penjualan Dengan Berbasis Web. Jurnal SIMETRIS, 7(2), 703.

[12] Ardani, N. R., \& Fitriana, N. "Sistem Rekomendasi Pemesanan Sparepart 
Jurnal Ilmiah Rekayasa dan Manajemen Sistem Informasi, Vol. 5, No. 1, Februari 2019, Hal. 99-108 e-ISSN 2502-8995 p-ISSN 2460-8181

Dengan Algoritma FP-Growth". Seminar Nasional Aplikasi Teknologi Informasi Dan Multimedia, 6-7. 2016.

[14] Rezkiani, "Implementasi Data Mining dengan Algoritma Apriori untuk Menentukan Merek Sepatu yang Diminati pada Mahasiswa Pascasarjana Kelas 14.1A.01 STMIK NUSA MANDARI Jakarta" ISBN : 978-602-72850-1-9. 